\title{
Essay mills and other contract cheating services: to buy or not to buy and the consequences of students changing their minds
}

Michael Draper ${ }^{1 *}\left(\mathbb{D}\right.$, Thomas Lancaster $^{2}$, Sandie Dann ${ }^{3}$, Robin Crockett ${ }^{3,4}$ and Irene Glendinning ${ }^{5}$

* Correspondence: m.j.draper@ swansea.ac.uk

'Swansea University, Swansea, UK Full list of author information is available at the end of the article

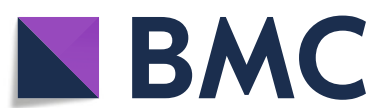

(c) The Author(s). 2021 Open Access This article is licensed under a Creative Commons Attribution 4.0 International License, which permits use, sharing, adaptation, distribution and reproduction in any medium or format, as long as you give appropriate credit to the original author(s) and the source, provide a link to the Creative Commons licence, and indicate if changes were made. The images or other third party material in this article are included in the article's Creative Commons licence, unless indicated otherwise in a credit line to the material. If material is not included in the article's Creative Commons licence and your intended use is not permitted by statutory regulation or exceeds the permitted use, you will need to obtain permission directly from the copyright holder. To view a copy of this licence, visit http://creativecommons.org/licenses/by/4.0/. The Creative Commons Public Domain Dedication waiver (http://creativecommons.org/publicdomain/zero/1.0/) applies to the data made available in this article, unless otherwise stated in a credit line to the data. 
Given that essay mills operate with apparent impunity in most jurisdictions, what are the legal rights of students who initially choose to commission a bespoke assignment, but then subsequently have second thoughts and change their mind? The right for students to withdraw has not been previously discussed in the literature, but it is necessary for student protection. The contract cheating industry is such that it preys on vulnerable students, leaving them positioned to becoming victims of unfair or illegal actions. Immediately someone makes an enquiry about using a third party to complete their assessments, they become open to threats of exposure. Extortion threats that some of the authors have encountered involve students who have not actually purchased anything or not submitted the work provided.

A student may be unaware of consequences such as these when they are seduced by contract cheating provider marketing or may later realise the benefits that come from operating with academic integrity. Can such students withdraw from the contract they have made with a contract cheating provider and what are the risks if they decide to do so?

Essay mills are defined by the UK Quality Assurance Agency as organisations or individuals, usually with an online presence, that contract with students to complete assignments for a fee (QAA 2020). The original definition of contract cheating, put forward by Clarke and Lancaster (2006) refers to "the submission of work by students for academic credit which the students have paid contractors to write for them". Despite the original paper describing contract cheating examples of varied assessment types, most notably computer programming, some subsequent researchers have equated the term solely with written assessments. Commentators, such as Bretag et al. (2018) have supported Clarke and Lancaster's (2006) original discussion by suggesting that contract cheating needs to be considered as a nuanced problem that extends beyond essay mills.

One such nuance asks when contract cheating begins. If a student puts forward a request to outsource their assessments, is this cheating? If they commission and receive work but do not submit it, have they contract cheated? Other terms are sometimes used synonymously with contract cheating, including assignment outsourcing, commissioning, also essay mills and ghost-writing, all depending if the discussion relates to the student or the contract cheating provider. There are also wider concerns such as facilitation, where students act as agents for contract cheating providers, helping to funnel more business their way in exchange for a financial reward or a discount on future assignment orders.

Contract cheating is arguably more serious than other forms of academic misconduct because there is no honest engagement or endeavour on the part of students who engage in such activities. Students who plagiarise or collude with other students also preparing assignments need to know enough about the subject in question in order to plagiarise or compile relevant material. By contrast, all contract cheating students need to know is how to share their assignment briefs and arrange any payments. All agents and facilitators need to know is how to put people in contact with each other or to simply forward contact details (Draper et al. 2017).

Students can have original essays and assignments produced for them without payment, for instance by relying on friends or family. They can also make arrangements with individual writers. Underground networks of writers operate in many university courses where students can ask another classmate or recent graduate to write an extra 
version of an assignment for them (Lancaster et al. 2019). Students also directly approach individual writers operating online through their own websites, social media and third-party sites (Lancaster 2019a, 2019b).

The focus of this paper is on services arranged through commercial providers which allow students to have assignments completed for them. The paper reviews how essay mills operate, discusses how students form contracts with essay mills, students' legal rights to withdraw from contracts and how institutions should respond whilst still respecting their duty of care to students. Sharp practices operated by contract cheating providers are explained throughout. The intention of the paper is to not only provide examples to share with students, discouraging them from engaging with the contract cheating industry, but also to ensure that institutions update their academic regulations, policies and procedures to respond to the growing complexity of contract cheating and the possible responses of academic institutions if a student wishes to terminate an agreement with an essay mill.

\section{Background}

The contract cheating industry

To understand the legal discussion presented in this paper, an understanding of how the contract cheating industry operates is important. Although research into the operation of the industry is still in its infancy, all indications are that this industry is massive, complex and deceptive (Crockett and Maxwell 2021; Rigby et al. 2015). This section discusses the operation of the essay mill industry, from the range of types of essay mills available, addressing how they recruit and develop new customers, through the production and submission of finished original essays.

This section provides only a high-level overview and the actual operation of essay mills can be much more complex. For example, a new contract cheating provider can buy off-the-shelf software to run their essay mill and, for a price, tap into existing networks of writers and quality assurance services without needing to set up this complex business operation for themselves.

Ultimately, it has to be remembered that the raison d'etre of essay mills is to make as much money as possible. It is not about the welfare of the customers, despite what the web sites and marketing materials may claim. This is an industry where providers will exploit any angle to persuade their customers to pay them more money. For example, essay mill employees may join a student suspected of academic misconduct at their University panel or write a letter of reply to an allegation of misconduct - for a substantial fee. All this often takes place beyond the reach of any national legislation.

\section{The spectrum of contract cheating providers}

At one end of the spectrum, contract cheating can involve well-established registered companies, some of which are operating as legitimate and very lucrative businesses. As discussed earlier, in very few administrations are these companies illegal. Such companies are responding to an acknowledged strong demand for a range of services and are able to make a lot of money.

At the other end of the spectrum are individuals, typically students, graduates, academics, and some falsely claiming to be qualified, who are directly or indirectly 
supplying work on demand for both students and academics. The recompense is normally financial, but there can be alternative rewards for small-time players, including sexual and other favours. In some cultures, pressures about loyalty to family or social contacts can place demands on individuals that compel them to become ghost-writers (Glendinning 2020).

In the middle of this continuum are ghost-writing individuals and fledgling essay mills, who may be going through agents to find work or bidding for work through auction sites. Most ghost-writers and the intermediaries justify their actions by saying this is their way of making a living or supplementing their other income, as discussed for example by Shahghasemi and Akhavan (2015).

\section{How contract cheating providers develop custom}

How contract cheating providers develop connections with potential customers is of interest. The methods used are varied and can appear innovative. Services optimise their sites to appeal to students based on academic discipline or location, often with the same essay mill operating with different front ends (Lancaster 2020). For example, a student who searches online for "nursing essay help" could be directed to an essay mill shop-front containing photos of smiling nurses, and a student searching for "law essay help" could be sent to an essay mill shop-front with photos of graduating lawyers, but behind the fronts these are operated by the same firms relying on the same groups of writers.

Social media is heavily used by contract cheating providers (Lancaster 2019b) with students posting even the slightest frustration with their essays on Twitter being regularly approached by companies offering these writing services (Amigud 2020). Often a commission payment is available to anyone referring business to an essay mill and job advertisements are posted by established mills to recruit recent graduates to go back to their campuses, infiltrate key events such as student association meetings and social events and recruit both customers and new agents. This can result in students working as agents or social media influencers, fake essay mill review sites that operate by collecting commission payments for introducing new custom to essay mills and even essay mills setting up fake student profiles to present themselves as a supportive environment for dissatisfied students.

Once a student has contacted or been referred to an essay mill, many more marketing techniques are used to ensure that students buy from them. Essay mills try to collect student email addresses by offering discounts. They use online chat to engage with students. Ritter (2005) noted how essay mills use language preying on students being dissatisfied with their courses to sell their services to them. Essay mills often present what they are doing as ('tutorial') support. Hersey and Lancaster (2015) discussed how some students consider assignments simply as commodities available to be bought and sold, and essay mills also rely on such student viewpoints.

\section{The operation of a typical essay mill}

Behind the scenes, many essay mills operate using a complex, software-driven writing and quality assurance process. Essay mills recruit writers, often using similar techniques to the ones they use to recruit students. In general, writing work is poorly paid with 
only a small percentage of the fee paid by a student going to the end-writer (Lancaster 2019a).

One example of an internal model used by essay mills has been described in the literature (Ellis et al. 2018). A variant is presented here. Received orders are first checked by an administrator to ensure they are legitimate and can be completed. Some orders are rejected, but those that pass scrutiny are made available to writers. This often uses a bidding process, where writers pitch against one another to write the essay, a process similar to that seen in the earliest contract cheating study (Clarke and Lancaster 2006). Once completed, further internal quality checks are made, which may include the use of automated tools to ensure plagiarism is avoided or disguised. Writers can be penalised if their work is of poor quality. Once internally approved, the work is made available to the student, who either accepts it, or returns it for revisions through a backand-forth process. If a student remains dissatisfied, they may raise their concerns with higher levels of essay mill management through a dispute process.

Even if a student accepts work from an essay mill, the end result is not risk free. The essay mill has the student's contact details and can continue to market to them. Students can be required to continue to buy or they risk being blackmailed, an area which most students appear unaware of (Yorke et al. 2020). Writers disgruntled with the essay mill they work for can often figure out student contact details and their institution and may try and extort money from them directly or inform the educational institution of their impropriety. Also, once a student submits commissioned work via text-matching software, they become potentially identifiable by the company they used, whatever the precautions they had taken up to that point.

\section{The legal grounds for students changing their mind Contract formation}

The first question to be addressed asks when a student commissions academic work, does a legally binding commitment or contract of purchase form? This is not a trivial question. An analysis of the behaviours and wider contractual relationships involved in contract cheating was undertaken by Draper et al. (2017).

Irrespective of jurisdiction, formation of a legally binding contract normally requires an offer to contract, an unqualified acceptance of that offer and its terms without variation, with the acceptance being communicated to the person making the offer with an intention to create or enter into a legal relationship with the parties to the contract having legal capacity, including by age and mental capacity.

In major European jurisdictions the existence of an agreement is usually demonstrated by the identification of at least an offer and acceptance (Jansen and Zimmermann 2011: 636-637). This is also the case in Australia. Some jurisdictions, such as England and Wales, also require the movement of consideration or benefit between the parties for a legally enforceable contract to be created, the usual example being the payment of money in return for the service or goods supplied. In such circumstances the student receives the completed assignment and the essay mill receives money by way of consideration.

The precise terms of the contract will depend upon the terms and conditions specified by the supplier and any other terms implied to make the contract work. Some 
jurisdictions, particularly in the counties identified above, intervene in the freedom to contract through the imposition of implied or imposed contractual terms to protect individuals contracting in a personal capacity, typically known as a consumer, as opposed to contracting in a business capacity. However, while the transaction may be made from the student's end in a country with consumer protection, due to the nature and operation of essay mill sites, these rights can be compromised when the transaction occurs across international borders (Durovic 2020).

Intervention is needed because contracts made by a business with an individual acting in a personal capacity, known as consumer contracts, usually have the following specific characteristics:

1. They are pre-drafted by one party as a standard form contract. Normally this means they are drafted by the essay mill rather than the student.

2. The express terms of the contract, usually referred to as the standard terms and conditions, are not usually subject to negotiation. This means that a consumer such as a student must usually accept the pre-drafted terms and conditions as they are if they want to obtain the desired service such as the supply of the essay.

3. They are entered into in circumstances in which neither party is known to the other with unequal bargaining power and commercial sophistication. A student is at a significant disadvantage in understanding the terms of the contract compared with the essay mill that drafted them, and is bound by the terms of the contract of supply, even if they have not read or understood them, provided there is reasonable notice of and a reasonable opportunity to read the terms and conditions before the contract is made.

When a student is given reasonable notice of and a reasonable opportunity to read the terms and conditions of the proposed contract before clicking 'I agree to the terms and conditions' or 'I accept the terms and conditions' a binding and enforceable contract will be made on those terms at some point in the ordering process when there is a clear offer and acceptance of the terms of the contract.

Further, when a contract is made with a consumer, further additional implied or imposed contractual terms and protections for the benefit of the consumer may apply. These depend on the country or the legal jurisdiction in which the contract is made or the law which applies to the contract usually by an express term known as a governing law clause.

Durovic $(2020,5)$ notes that "consumer law and policy is faced with two major challenges, which need to be addressed adequately on the global scale. The first one is an increasing number of cross-border transactions, whereas the second one is the rise of Internet as the leading global marketplace and the entire technological developments which have disrupted the traditional consumer law".

As essay mills tend to operate across national boundaries it is crucial that an essay mill states, in an express term of the contract, the law and jurisdiction which is to apply to the contract having regard to its legal interpretation and enforcement, in terms of governing law and/or jurisdiction clause. However, many essay mills do not provide this. 
The lack of express terms may not, in itself, prevent a national court from asserting jurisdiction if their consumer(s) are at risk. As Durovic (2020) notes, there are international conventions dealing with governing law, and consumer rights and permissible use of personal information gathered in online environments.

Express terms which are relevant to this paper are those requiring the payment of a deposit on order, the cancellation of a contract and those allowing for personal information to be taken and used in addition to a name and contact details. For example, the student may be required to provide the name of the institution at which they are studying, student number and photographic identification, none of which immediately appear relevant to the subject matter of the contract.

\section{Contractual tricks}

Many of the tactics used by essay mills could be considered unfair. They know that consumers, including students, do not usually read the terms and conditions of the contract before clicking and will not therefore know in any detail what they have agreed or indeed what their rights or obligations maybe under the terms of the contract beyond a superficial understanding that payment at some point will be required for the work (Rogerson 2017). For example, Berreby (2020) reported in The Guardian newspaper that hundreds of College students joining a new social network did not notice a clause where they promised to give away their first-born children.

The collection and use of other types of personal information and data beyond name and Institution etc. as a result of online contracts are a current concern. For example, the Australian Competition and Consumer Commission (2019) observed a range of practices used by platforms that did not conform with existing consumer laws, but nevertheless may not be effective at deterring conduct that is detrimental to consumers. Given the increasing value of data, some businesses engage in conduct designed to elicit data or information the collection of which may be considered unfair to consumers.

These design patterns have become known as 'dark patterns' because they prompt, mislead or sometimes force consumers to provide their personal data or cause them to sign up to services, often without the consumer realising (Bignull 2010). Dark patterns take advantage of skim reading of text and other unconscious habits through familiarity with user interfaces to procure either money or data from consumers, often without their fully informed consent (ibid). At their most benign dark patterns nudge the behaviour of consumers to a desired outcome in which the consumer unconsciously provides personal data or agree to its use by the business. These patterns can have significant impact on unsophisticated students as the next section discusses.

\section{When does contract acceptance take place?}

After placing an order for work a student may change their mind and seek to cancel the order. As a matter of general contract law, a student may withdraw their offer without liability at any time before the contract is formed by acceptance of the order by the essay mill. Depending on the terms and conditions, the offer made by the student may be accepted so that an enforceable contract arises as soon as the order is processed, or when the payment or deposit is taken, or upon dispatch of the essay to the student. 
However as noted above while a legal contract may exist it does not necessarily follow that it will be enforceable across international borders and this point should be borne in mind when considering the analysis that follows - particularly when there are unscrupulous operators in this area.

A legal analysis of the typical order process discussed in the background section would conclude that acceptance likely occurs when the order status is made available to writers within an essay mill or upon the status of the order being made available to the student for review. The precise moment of the creation of an enforceable contract will depend in the main upon the terms and conditions of supply. Options to revise or embark on dispute resolution are likely to be interpreted as express contractual rights which operate after the formation of the contract.

Thus, a student would be legally entitled to withdraw their offer to purchase work and without liability, because there is no contract, before the change in status of the order. After change in status of the order it is possible that the contract contains an express term allowing for cancellation subject usually to loss of any deposit or some other sum which genuinely represents the loss suffered by the essay mill, for example payments made to a writer. In such circumstances it is important that a student follow the terms of cancellation precisely in order to legally terminate the contract and limit the loss under the contract.

Without an express term allowing for termination of the contract, for example after a change in the status of the order to 'available', any attempt by one party to cancel a contract before performance of that contract will usually amount to a repudiatory breach of contract entitling the innocent party to damages in respect of any loss suffered if and when that breach is accepted. From the point of view of an essay mill that will usually be payments contracted to be made to a writer for their work and other administration costs.

Consumer contracts will usually have implied rights of cancellation attached to them by legislation and/or regulations. In England and Wales this will mean the Consumer Rights Act 2015 and the Consumer Contracts (Information, Cancellation and Additional Charges) Regulations 2013.

Information about the rights of a consumer to cancel a contract should be detailed by the supplier and made available to the consumer before the contract is made. Failure to provide the information to a consumer as required by the regulations will allow a consumer to claim that a breach of contract has occurred and to seek an appropriate remedy. However as noted above these rights and protections may not be available or enforceable in a cross-border context.

\section{Consumer protection and rights of cancellation}

In England and Wales as the contract between the essay mill and student will normally be concluded remotely, namely online, a student's rights to cancel the contract are to be found in the Consumer Contracts (Information, Cancellation and Additional Charges) Regulations 2013. These are more generous than if the contract had been concluded face-to face. These regulations also apply to all auctions including online auctions. Online auctions result in contracts created at a distance rather than face to face. 
As considered earlier the formation of a contract requires an offer and acceptance of that offer. It is likely that the website of an essay mill is treated in the same way as a shop window. The website is not an offer of a service or goods, but an invitation to treat, or in other words an invitation to another to make an offer to buy or order on stated terms and conditions. A student placing an order online is making an offer to buy an essay and not to accept the offer of the essay mill to supply an essay.

Depending on the terms and conditions the offer made by the student may be accepted so that an enforceable contract arises as soon as the order is processed or made 'available' or the deposit is taken or upon dispatch of the essay to the student as discussed above. As a matter of general contract law, a student may withdraw their offer without liability at any time before the contract is formed by acceptance. Once the contract is formed then a student will have statutory rights of cancellation without giving any reason for cancellation within a specified time. These rights can only be excluded in very limited circumstances which require the express and fully informed consent of the consumer. This means that they cannot be excluded by standard terms and conditions.

Rights of cancellation differ if the contract relates to goods or digital content or services. Both allow for cancellation within a 14-day period but the calculation of that period will be different if the contract relates to goods or digital content or services. If the supply of an essay is treated as the supply of goods then under the regulations a student has a right to cancel an order for an essay as soon as the order is placed up until 14 days from the day after the student receives the essay with a right to a refund within 14 days of either the supplier getting the goods back or the consumer providing evidence of having returned the goods. If the supply of an essay is treated as the supply of digital content, not supplied on a tangible medium or a service, then a student has 14 days starting from the day after the contract was made in which to cancel that contract with a right to a refund of money paid.

The regulations do allow for service to be started within the cancellation period and for a charge to be made providing that the consumer has expressly requested this. A consumer loses their right to cancel a service contract that has been performed fully within the cancellation period, providing they requested this and acknowledged that they would lose their right to cancel once the contract had been performed fully. It is likely that a contract for the supply of an essay will be treated as a contract for the supply of goods.

Additional rights are available under the UK Consumer Rights Act 2015 to reject a product if not of satisfactory quality or fit for purpose. In the context of a paid for assignment this will be difficult to establish against assignment briefs as marking has a degree of subjectivity. Essay mills seek to mitigate such problems through terms and conditions allowing for rewriting or some other form of offer or compensation. Similar consumer rights apply across Europe as the Act and Regulations are based on European Directives.

As Sutherland-Smith and Dullaghan have observed (2019), purchasers of contract cheating don't always get what they pay for. Therefore, cancelation rights are a particularly useful addition to any express dispute resolution provided by the terms and conditions of the essay mill. Furthermore, a student may simply change their mind and 
cancel the order because of the risks attached to submission or their conscience gets the better of them or because of an institutional campaign or peer pressure or support.

The danger for a student is that they may forget, or may not feel they have been told at the outset when the contract is formed, that strict time limits normally apply to the use of statutory cancellation rights. This can limit their ability to raise a dispute with the essay mill.

In summary therefore, and subject to the point that rights and protections may not be available or enforceable in a cross-border context, a student has a right:

1. To cancel the order at any time before it is accepted and a contract formed

2. To cancel the contract under express cancellation rights but normally at a financial cost through loss of deposit or other recoverable loss

3. To cancel the contract under jurisdictional cancellation rights without financial cost unless expressly excluded in the circumstances described above

\section{Institutional responses to the student right to withdraw}

Although the paper has established that students have the legal rights of cancellation, it cannot be assumed that the essay mill will simply demur to the exercise of those rights. Therefore, it is recommended that institutions have their own responses prepared ready for when students wish to withdraw from contracts with essay mills.

Students do run the risk of blackmail and extortion if they proceed with a contract. They may discover the risk, ask to withdraw from their contract, but have such a request declined or ignored. They may also have used a contract cheating provider previously, not realising they would be expected to continue to purchase future pieces of work from them.

Universities should provide a mechanism for students to confess and to seek support. Students should be encouraged to use this. Such a mechanism would also be a welcome development for universities. Not only would it save considerable time and resources in investigations and hearings, but there is potential for accessing new intelligence about essay mills that would not otherwise have been found.

Sanctions to negate an unfair advantage are often unavoidable in such a situation. Students cannot be seen to be rewarded for assessments they did not complete themselves. However, in return for their cooperation, students could perhaps be taken through a less formal process, combined with a programme of support, guidance and monitoring, to ensure they are not tempted to do this again (QAA 2020: 12-17). This might include, for example, a situation in which a student who confesses shortly after submitting a single commissioned assignment could be provided with the opportunity to redeem themselves, for instance by repeating the work, subject to measures such as grade caps designed to neutralise the potential for an unfair advantage.

In some cases, a light touch approach may not be possible. Consider, for example, a situation involving a final-year degree student confessing to having routinely commissioned over three or four (or more) years of study, with a progression dependent on pre-requisites from one year to the next. In addition, there might be course-specific regulations arising from professional institutional accreditation that over-ride more general regulations. 
If a student does not confess, then they face serious and complicated risks. Put simply, once a student communicates with an essay mill, even if only making an enquiry, then that essay mill has some version of their identity and contact details on a database (possibly overseas) which is potentially available to other parties. Any commissioning and payment would provide additional details, irrespective of any subsequent change of mind. Even if a student manages to conceal their identity and their institution when commissioning an assignment, once that assignment is submitted through similarity checking software, then the student is potentially traceable. All a blackmailer needs to do is submit the assignment to the same similarity checking software themselves, possibly via a facilitator's account or an account that's been compromised, see which institution is identified as the main result, and then go 'phishing' at that institution, possibly with the assistance of a staff or student facilitator at that institution, Of course, if they've already unsuccessfully tried to blackmail the student, they might simply 'whistle-blow' to that institution with sufficient evidence to support the allegation. Essay mills are not famous for their ethical principles: they are interested in making money. A database of student details is a marketable commodity that could be traded to unscrupulous third parties, who themselves can engage in extortion.

Raising students' awareness about these in-built dangers of engaging in contract cheating is not just part of the deterrence measures for educational providers, it is also part of their duty of care.

\section{Conclusion}

This paper serves to emphasise that a decision by a student to resort to contract cheating can be changed. That change of mind or heart is supported by the law and should be reflected in institutional regulations and policies. The right of students to change their mind is not a message that has been addressed in the literature or heard often in conferences or within institutions; but, nevertheless, it is important and needs to be discussed with students.

It should be possible for a student to change their mind and do so in way that offers them a degree of protection from the sharp and unscrupulous practices of essay mills, as identified in this paper. To benefit from that protection the student must disclose to the institution the arrangements they made with the essay mill. To do this will take a significant amount of courage on the part of a student. It is therefore critical that institutional regulations and policies provide a framework to enable and support such a decision, ideally with support from student organisations. In so doing, institutions need to uphold the fundamental aim of fostering academic integrity as a core value for all.

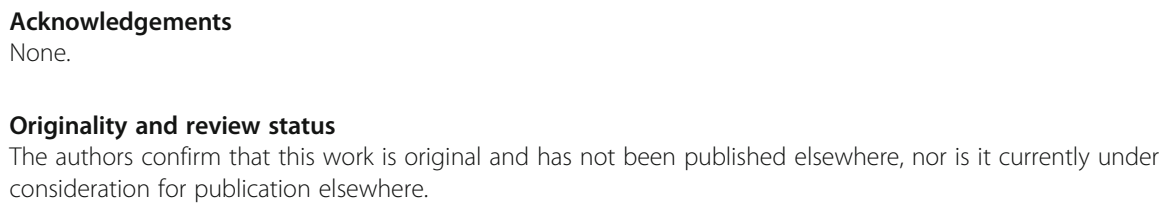

Funding 
Availability of data and materials

No data was used in the writing of this article.

\section{Declarations}

\section{Competing interests}

The authors declare that they have no competing interests.

\section{Author details}

${ }^{1}$ Swansea University, Swansea, UK. ${ }^{2}$ Imperial College London, London, UK. ${ }^{3}$ Loughbourgh University, Loughborough, UK. ${ }^{4}$ University of Northampton, Northampton, UK. ${ }^{5}$ Coventry University, Coventry, UK.

Received: 25 January 2021 Accepted: 26 May 2021

Published online: 29 June 2021

\section{References}

Amigud A (2020) Cheaters on twitter: an analysis of engagement approaches of contract cheating services. Stud High Educ 45(3):692-705. https://doi.org/10.1080/03075079.2018.1564258

Australian Competition and Consumer Commission. Digital Platforms Inquiry 2019. https:/www.accc.gov.au/publications/ digital-platforms-inquiry-final-report.

Berreby, D. (2020). Click to agree with what? No one reads terms of service, studies confirm. The Guardian (2020). https:// www.theguardian.com/technology/2017/mar/03/terms-of-service-online-contracts-fine-print. Accessed 4 May 2021.

Bignull, H. (2010). Dark Patterns. https://www.darkpatterns.org/.

Bretag T, Harper R, Burton M, Ellis C, Newton P, Rozenberg P, Saddiqui S, van Haeringen K (2018) Contract cheating: a survey of Australian university students. Stud High Educ 44(11):1837-1856. https://doi.org/10.1080/03075079.2018.1462788

Clarke R, Lancaster T (2006) Eliminating the successor to plagiarism? Identifying the usage of contract cheating sites. In: Proceedings of 2nd international plagiarism conference. JISC Plagiarism Advisory Service, Newcastle

Crockett RGM, Maxwell R (2021) Ethical and privacy considerations of the marketing tactics used by some academic assignment providers: a case-study. In: Proceedings 7th European Conference on Academic Integrity and Plagiarism, ENAl, 7-9 June $2021 \mathrm{https}: / /$ academicintegrity.eu/conference/conferenceproceedings/

Draper MJ, Ibezim V, Newton PM (2017) Are essay Mills committing fraud? An analysis of their behaviours vs the 2006 fraud act (UK). Int J Educ Integr 13(1):3. https://doi.org/10.1007/s40979-017-0014-5

Draper MJ, Newton PM (2017) A legal approach to tackling contract cheating. Int J Educ Integr 13(1). https://doi.org/10.1007/ s40979-017-0022-5

Durovic M (2020) International consumer law: what is it all about? J Consum Policy 43(1):125-143. https://doi.org/10.1007/s1 0603-019-09438-9

Ellis C, Zucker IM, Randall D (2018) The infernal business of contract cheating: understanding the business processes and models of academic custom writing sites. Int J Educ Integr 14(1):1. https://doi.org/10.1007/s40979-017-0024-3

Glendinning I (2020) The role of quality assurance and regulatory organizations to promote academic integrity. In: A Research Agenda for Academic Integrity. Edward Elgar Publishing, UK. https://doi.org/10.4337/9781789903775.00008

Hersey C, Lancaster T (2015) The online industry of paper mills, contract cheating services, and auction sites

Jansen N, Zimmermann R (2011) Contract formation and mistake in European contract law: a genetic comparison of transnational model rules. OJLS 31(4):625-662. https://doi.org/10.1093/ojls/ggr011

Lancaster T (2019a) Profiling the international academic ghost writers who are providing low-cost essays and assignments for the contract cheating industry. J Inf Commun Ethics Soc 17(1):72-86. https://doi.org/10.1108/JICES-04-2018-0040

Lancaster T (2019b) Social media enabled contract cheating. Can Perspect Acad Integrity 2(2):7-24. https:/doi.org/10.11575/ cpai.v2i2.68053

Lancaster T (2020) Academic discipline integration by contract cheating services and essay Mills. J Acad Ethics 18(2):1-13. https://doi.org/10.1007/s10805-019-09357-x

Lancaster T, Glendinning I, Foltýnek T, Dlabolová D, Linkeschová D (2019) The perceptions of higher education students on contract cheating and educational corruption in south East Europe. J Educ Thought/Rev La Pensée Educa 52(3):209-227. https://doi.org/10.11575/jet.v52i3.69722

QAA (2020) Contracting to cheat in higher education. How to address contract cheating, the use of third-party services and essay mills, 2nd edn https://www.qaa.ac.uk/docs/qaa/guidance/contracting-to-cheat-in-higher-education-2nd-edition.pdf

Rigby D, Burton M, Balcombe K, Bateman I, Mulatu A (2015) Contract cheating \& the market in essays. J Econ Behav Organ 111:23-37, ISSN 0167-2681. https://doi.org/10.1016/j.jebo.2014.12.019

Ritter K (2005) The economics of authorship: online paper Mills, student writers, and first-year composition. Coll Compos Commun 56(4):601-631 https://www.jstor.org/stable/30037888

Rogerson AM (2017) Detecting contract cheating in essay and report submissions: process, patterns, clues and conversations. Int J Educ Integr 13(1):10. https://doi.org/10.1007/s40979-017-0021-6

Shahghasemi E, Akhavan M (2015) Confessions of academic ghost authors: The Iranian Experience. Sage Open, US. https:// doi.org/10.1177/2158244015572262

Sutherland-Smith W, Dullaghan K (2019) You don't always get what you pay for: user experiences of engaging with contract cheating sites. Assess Eval High Educ 44(8):1148-1162. https://doi.org/10.1080/02602938.2019.1576028 
UK Government Consumer Contracts (Information, Cancellation and Additional Charges) Regulations 2013. https://www. legislation.gov.uk/uksi/2013/3134/contents/made. Accessed 4 May 2021.

UK Government Consumer Rights Act 2015. https://www.legislation.gov.uk/ukpga/2015/15/contents/enacted. Accessed 4 May 2021.

Yorke J, Sefcik L, Veeran-Colton T (2020) Contract cheating and blackmail: a risky business? Stud High Educ:1-14. https://doi. org/10.1080/03075079.2020.1730313

\section{Publisher's Note}

Springer Nature remains neutral with regard to jurisdictional claims in published maps and institutional affiliations.

Ready to submit your research? Choose BMC and benefit from:

- fast, convenient online submission

- thorough peer review by experienced researchers in your field

- rapid publication on acceptance

- support for research data, including large and complex data types

- gold Open Access which fosters wider collaboration and increased citations

- maximum visibility for your research: over $100 \mathrm{M}$ website views per year

At $\mathrm{BMC}$, research is always in progress.

Learn more biomedcentral.com/submissions 